\title{
PENGARUH MODEL PEMBELAJARAN PROBING-PROMPTING TERHADAP KEMAMPUAN MENULIS NASKAH PIDATO SISWA KELAS IX MTs. MALNU KABUPATEN LEBAK
}

\author{
${ }^{1}$ Meliyawati, ${ }^{2}$ Ani Priska Andayani, ${ }^{3}$ Eri Herdiana \\ Universitas Mathlaul Anwar Banten \\ Email: meliyawati3@gmail.com
}

\begin{abstract}
Abstrak. Pengaruh Model Pembelajaran Probing prompting terhadap Kemampuan Menulis Naskah Pidato pada Siswa Kelas IX MTs. Malnu Kabupaten Lebak Rumusan dalam penelitian ini adalah untuk menjawab pertanyaan yang dikemukakan tentang apakah terdapat pengaruh model pembelajaran Probing prompting terhadap kemampuan menulis naskah pidato pada siswa Kelas IX MTs. Malnu Kabupaten Lebak Metode yang digunakan dalam penelitian ini adalah metode eksperimen, dengan mengambil siswa Kelas IX MTs. Adapun teknik sampel menggunakan classter random sampling. Hasil undian yang dilakukan terhadap kedua yang ada diperoleh yaitu kelas X-B sebagai kelas eksperimen dan Kelas IX-A sebagai kelas kontrol. Masing-masing kelas berjumlah 22 dan 25 siswa. Berdasarkan data nilai tes kemampuan menulis naskah pidato dengan menggunakan model pembelajaran probing prompting siswa Kelas IX. Hal tersebut ditunjukan bahwa rata-rata kemampuan tersebut adalah 79,5 dengan nilai terendah 65 dan nilai tertinggi 90 , memiliki nilai median 80,2 dan modus 81,5. Sedangkan kemampuan menulis naskah pidato dengan menggunakan model ekspositori pada siswa Kelas IX MTs. Malnu Kabupaten Lebak sebagai kelas kontrol cukup. Hal tersebut ditunjukan oleh hasil pengujian hipotesis (Uji t) dengan taraf signifikan 0,05 yaitu $t_{\text {hitung }}$ 5,00 lebih besar dari $\mathrm{t}_{\text {tabel }}$ 2,026 maka $\mathrm{H}_{\mathrm{O}}$ ditolak dan $\mathrm{H}_{\mathrm{I}}$ diterima.
\end{abstract}

Kata Kunci: Metode Probing prompting dan Kemampuan Menulis Naskah Pidato

Abstract. The aim of the research is to find whether there is any influence of learning model of ProbingPrompting on the ability to write speech texts. The researcher used quantitative research using experimental design. The sample technique used classter random sampling. The results of the lottery performed on the two available were $X-B$ class as the experimental class and IX-A class as the control class. Each class was 22 and 25 students. Based on the test scores of the ability to write a speech script by using a probing prompting learning model for Class IX students. It shows that the average ability is 79.5 with the lowest value of 65 and the highest value of 90, has a median value of 80.2 and mode 81.5. While the ability to write speech scripts by using expository models in other Class. This is shown by the results of hypothesis testing ( $t$ test) with a significant level of 0.05 , that is 5.00 is greater than t table 2.026, then $\mathrm{HO}$ is rejected and $\mathrm{HI}$ is accepted. It means that there is a positive influence on the use of probing prompting learning models on the ability to write speech scripts.

Keywords: Probing prompting method and speech writing ability 


\section{PENDAHULUAN}

Komunikasi merupakan suatu kegiatan yang dilakukan oleh manusia yang dapat mempermudah interaksi satu sama lainnya, dengan berkomunikasi manusia dapat mengungkapkan hal-hal yang dapat diungkapkan baik secara lagsung maupun tidak. "Sebuah penelitian mengungkapkan bahwa $70 \%$ waktu bangun kita digunakan untuk berkumunikasi. Komunikasi menentukan kualitas hidup kita" (Rakhmat, 2005: vii). Untuk dapat mengembangkan kemampuan berkomunikasi, siswa dilatih melalui kegiatan pembelajaran berbahasa yang dilakukan secara terpadu. Salah satu keterampilan berbahasa adalah keterampilan berbicara. Berbicara adalah suatu kegiatan mengucapkan bunyi-bunyi atau katakata untuk menyampaikan pikiran atau pendapat kepada pendengar sebagai salah satu bentuk komunikasi nonverbal. Berbicara melibatkan unsur-unsur pembicara sebagai penyampai pesan atau ucapan dan pendengar sebagai penerima pesan.

Guna mempersiapkan pidato, khususnya bagi pemula, maka dilakukan melalui pidato dengan naskah. Untuk itu pembelajaran berbahasa Indonesia di sekolah menuntut siswa untuk menguasai empat keterampilan berbahasa sekaligus. Empat keterampilan berbahasa tersebut adalah menyimak, berbicara, membaca, dan menulis. Menyimak dan membaca merupakan keterampilan yang bersifat reseptif sebab siswa hanya menerima dan meresapi apa yang disimak dan dibaca. Sementara itu, berbicara dan menulis merupakan keterampilan yang produktif karena siswa menghasilkan sesuatu melalui kegiatan berbicara dan menulis.

Menulis merupakan kegiatan pembelajaran yang paling sulit di antara keterampilan berbahasa lainnya. Kegiatan menulis mengharuskan siswa mempunyai wawasan yang luas dan harus banyak membaca untuk meningkatkan hasil tulisannya dengan baik. Sehubungan dengan menulis ini, Tarigan (2008:4) menyatakan bahwa menulis merupakan suatu keterampilan berbahasa yang dipergunakan untuk berkomunikasi secara tidak langsung, tidak secara tatap muka dengan orang lain. Menulis merupakan suatu kegiatan yang produktif dan ekspresif. Dalam kegiatan menulis, penulis harus terampil memanfaatkan grafologi, struktur bahasa, dan kosakata. Keterampilan menulis tidak akan datang secara otomatis, melainkan harus melalui latihan dan praktek yang banyak dan teratur. Menurut Wiyanto (2004:8), keterampilan menulis tidak diperoleh secara cepat, melainkan perlu waktu yang cukup lama untuk belajar dan berlatih. Latihan-latihannya pun harus bertahap, termasuk didalamnya latihan menulis naskah pidato.

Model pembelajaran yang baik akan mendapatkan hasil belajar yang baik pula dan model pembelajaran yang kurang sesuai akan menghasilkan hasil belajar yang kurang maksimal. Menurut Surakhmad (2010:96), makin baik model pembelajaran yang digunakan maka akan makin baik pula pencapaian tujuan. Senada dengan pendapat Surakhmad, Pembelajaran probing

prompting adalah pembelajaran dengan cara guru menyajikan serangkaian pertanyaan yang sifatnya menuntun dan menggali sehingga terjadi proses berpikir yang mengaitkan pengetahuan tiap siswa dan pengalamannya dengan pengetahuan baru yang sedang dipelajari (Suherman, 2008:6). Selanjutnya siswa mengkonstruksi konsep-prinsip dan aturan menjadi pengetahuan baru, dengan demikian 
pengetahuan baru tidak diberitahukan

Berdasarkan alasan-alasan di atas, sehingga penulis tertarik untuk melakukan penelitian dengan judul "Pengaruh Model Pembelajaran Problem prompting terhadap Kemampuan menulis naskah pidato Siswa Kelas IX MTs. Malnu Kabupaten Lebak.

\section{METODE PENELITIAN}

Metode penelitian yang digunakan dalam penelitian ini adalah eksperimen. Pada penelitian ini terdapat dua variabel, yaitu variabel bebas dan variabel terikat. Variabel bebas atau variabel independen merupakan variabel yang mempengaruhi atau yang menjadi sebab perubahannya atau timbulnya variabel dependen (Sugiyono, 2008:39). Sebab perubahan itu dapat berupa faktor, kondisi, situasi, perlakuan atau tindakan. Oleh karena itu, variabel bebas dapat berpengaruh terhadap hasil eksperimen.

\section{PEMBAHASAN}

\section{Hakikat Menulis Naskah Pidato}

\section{a. Pengertian Menulis}

Menulis pada hakikatnya adalah suatu proses berpikir yang teratur, sehingga apa yang ditulis mudah dipahami pembaca. Sebuah tulisan dikatakan baik apabila memiliki ciri-ciri, antara lain bermakna, jelas, bulat dan utuh, ekonomis, dan memenuhi kaidah gramatika.

Zainurrahman

$(2013: 2)$

menyatakan bahwa menulis merupakan salah satu dari empat keterampilan berbahasa yang mendasar (berbicara, mendengar, menulis, dan membaca). Dewasa ini, keterampilan berpikir kritis (critical thinking) dan literasi (literacy skill) sudah menjadi keterampilan berbahasa lanjutan (advanced linguistic skill). Menulis merupakan kunci yang paling utama demi mencapai kesuksesan untuk mencapai predikat "mampu menulis dengan baik dan benar." Seseorang hanya bisa menciptakan sebuah tulisan yang baik jika dia rajin membaca, karena dalam interaksi antara seorang pembaca dan bacaan terdapat model tulisan yang dijamin (sebaliknya) keterbacaannya.

Sebagai salah satu

keterampilan berbahasa peran menulis sangatlah penting, terutama pada siswa yang masih duduk di bangku sekolah. Seperti halnya yang dikemukakan oleh para ahli mengenai pengertian menulis. Menulis adalah mengungkapkan pikiran, perasaan, pengalaman, dan hasil bacaan dalam bentuk tulisan, bukan dalam bentuk tutur (Djibran, 2008:17). Menulis adalah membuat huruf, angka, dan sebagainya dengan pena, pensil, cat, dan sebagainya melahirkan pikiran atau perasaan seperti mengarang, membuat surat, dan sebagainya dengan tulisan. Selanjutnya menulis adalah menuangkan gagasan, pendapat, perasaan, keinginan, dan kemauan, serta informasi ke dalam tulisan dan kemudian "mengirimkannya" kepada orang lain (Syafi'ie, 2008:45).

Berdasarkan analisis teori di atas, maka yang dimaksud dengan menulis adalah kemampuan menuangkan atau mengungkapkan ide/gagasan kedalam sebuah tulisan yang dapat dipergunakan untuk melaporkan, memberitahukan, dan mempengaruhi kepada siapa saja yang membacanya.

\section{b. Pengertian Menulis Naskah \\ Pidato}

Menulis naskah atau teks pidato pada hakikatnya adalah menuangkan gagasan ke dalam bentuk bahasa tulis yang siap dilisankan. Pilihan kosakata, kalimat, dan paragraf dalam menulis sebuah pidato sesungguhnya tidak jauh berbeda dengan kegiatan menulis naskah yang lain. Situasi resmi atau kurang resmi akan menentukan kosakata dalam menulis. 
Naskah pidato seperti juga naskah dialog, ditulis untuk ditampilkan. Perbedaanya, naskah dialog ditampilkan oleh beberapa orang, sedangkan pidato ditampilkan oleh seorang saja, komunikasi terjadi antara yang berpidato dengan pendengar. Sebenarnya, pidato harus selalu menggunakan naskah. Bila akan berpidato menggunakan naskah, maka harus menyiapkan naskah tersebut terlebih dahulu. Dengan demikian harus memiliki keterampilan menulis naskah pidato.

Pidato adalah upaya

menyampaikan gagasan dan pikiran untuk disampaikan kepada khalayak. (Fitriana,2013:149). Pidato adalah kata-kata yang disampaikan dan ditujukan kepada orang banyak. Pidato memiliki beberapa jenis diantaranya, pidato sambutan yang disampaikan pada awal sebuah acara atau pidato kenegaraan yang disampaikan oleh presiden. Pidato yang baik dapat memberikan suatu kesan positif bagi orang-orang yang mendengar pidato tersebut. Kemampuan berpidato atau berbicara yang baik di depan publik/ umum dapat membantu untuk mencapai jenjang karir yang baik.

Keterampilan berpidato adalah salah satu keterampilan produktif dalam keterampilan berbahasa siswa. Keterampilan berpidato dibutuhkan masyarakat untuk dipelajari dan dipraktikkan dalam rangka menyampaikan suatu gagasan yang menyangkut kepentingan orang banyak, yakni masyarakat pada umumnya.

Pidato yang baik dapat memberikan suatu kesan positif bagi orang-orang yang mendengar pidato tersebut, karena pada saat melakukan keterampilan berpidato tentu saja ada gagasan atau pendapat yang ingin disampaikan oleh pembicara kepada para pendengar. Pada saat melakukan pidato, hal yang harus diperhatikan selanjutnya adalah emosional pembicara. Karena emosional tentu saja dapat mempengaruhi isi pidato yang disampaikan. Tarigan (2008:28) berpendapat bahwa: "Perlu disadari bahwa tuntutan serta pertimbanan dalam situasi-situasi informatif lebih bersifat intelektual ketimbang emosional". Emosional dapat mempengaruhi isi pesan yang disampaikan pada saat berpidato.

Menurut Rakhmat (2007:64), kecemasan berkomunikasi adalah batu sandungan yang besar bagi seorang pembicara. Ia menghilangkan kepercayaan diri. Kecemasan berkomunikasi amat mempengaruhi kredibilitas komunikator. Kecemasan berkomunikasi tentu saja mempengaruhi berpidato seseorang, karena betapapun bagusnya pengorganisasian pesan yang ingin disampaikan, tanpa kepercayaan diri maka akan sulit untuk mengungkapkannya.

Dalam keterampilan berpidato tentu saja kita harus memiliki kemampuan berbicara yang baik, khususnya berbicara di depan orang banyak, orang yang dapat berbicara dengan baik di depan khalayak tentu saja dapat dengan mudah dalam menyampaikan pesan atau gagasan pada saat berpidato.

\section{Tinjauan tentang Model Pembelajaran Probing Prompting \\ a. Model Pembelajaran Probing Prompting}

Pembelajaran Probing adalah penyelidikan dan pemerikasaan, sementara prompting adalah dorongan atau menuntut. Probing prompting adalah pembelajaran dengan menyajikan serangkaian pertanyaan yang sifatnya menuntut dan menggali gagasan siswa sehingga dapat melejitkan proses berfikir yang mampu mengaitkan pengetahuan dan pengalaman siswa dengan pengetahuan baru yang sedang dipelajari (Huda, 2013: 281). Selanjutnya, siswa 
mengkronstruksi konsep-konsep atau aturan menjadi pengetahuan baru, dan dengan demikian pengetahuan baru tidak diberitahu. Pembelajaran probing-prompting sangat erat kaitannya dengan pertanyaan. Pertanyaan-pertanyaan yang dilontarkan pada saat pembelajaran ini disebut probing question. Probing question adalah pertanyaan yang bersifat menggali untuk mendapatkan jawaban lebih dalam dari siswa yang bermaksud untuk mengembangkan kualitas jawaban, sehingga jawaban berikut lebih jelas dan akurat dan beralasan.

Dari beberapa kesimpulan para ahli di atas, maka dapat disimpulkan bahwa model pembelajaran probing prompting ialah suatu model pembelajaran yang dapat meningkatkan proses berpikir siswa dalam menggali kemampuannya. Untuk menumbuhkan rasa percaya diri dalam melakukan kegiatan belajar mengajar dan berani bertanya hal-hal yang belum dipahami oleh siswa ketika dikelas, dengan cara guru memberikan pelayanan pada saat kegiatan belajar berlangsung. Model pembelajaran probing prompting adalah pembelajaran dengan cara guru menyajikan serangkaian pertanyaan yang sifatnya menuntun dan menggali sehingga terjadi proses berpikir yang mengaitkan pengetahuan tiap siswa dan pengalamannya dengan pengetahuan baru yang sedang dipelajari (Suherman, 2008:6). Model pembelajaran probing prompting merupakan salah satu model pembelajaran kooperatif. Berdasarkan asal katanya, probing artinya penyelidikan, pemeriksaan sedangkan prompting artinya mendorong atau menuntun. Model pembelajaran Probing Prompting berhubungan dengan pertanyaan yang dikenal dengan Probing question dan Prompting question.
Probing question adalah pertanyaan yang bersifat menggali untuk mendapatkan jawaban yang lebih lanjut dari siswa yang bermaksud mengembangkan kualitas jawaban, sehingga jawaban berikutnya lebih jelas, akurat serta lebih beralasan. Sedangkan Prompting question adalah pertanyaan yang diajukan untuk memberi arah kepada siswa dalam proses berpikirnya (Mayasari dkk, 2014:57).

\section{HASIL PEMBAHASAN}

\section{Data Hasil Tes Menulis Naskah Pidato Kelas Eksperimen}

Berdasarkan hasil penelitian tes menulis naskah pidato dengan menggunakan model pembelajaran probing prompting, setelah diberikan postes menulis naskah pidato, hasilnya diperoleh data sebagai berikut: jumlah skor nilai rata-rata 79,5 , skor tertinggi 90 dan skor terendah 65 , median 80,2 , modus 80,5 dan standar deviasi 6,68 . Dari data-data tersebut kemudian dibuat data distribusi, dengan menggunakan rumus Struges sebagai berikut :

Tabel 1

Nilai Kemampuan Menulis Naskah Pidato

Menggunakan Model Probing prompting

\begin{tabular}{|c|c|c|c|}
\hline Mean & Median & Modus & Standar Deviasi \\
\hline 79,5 & 80,2 & 81,5 & 6,68 \\
\hline
\end{tabular}

Berdasarkan data di atas, maka untuk lebih memperoleh gambaran kemampuan menulis naskah pidato lebih jelas, selanjutnya disajikan dalam bentuk tabel distribusi frekuensi berikut ini. 
Tabel 2

Daftar Distribusi Frekuensi Kelas Eksperimen

\begin{tabular}{|c|c|c|c|c|}
\hline No & $\begin{array}{l}\text { Interv } \\
\text { al }\end{array}$ & $\mathbf{F}$ & $\begin{array}{l}\mathbf{F}_{\text {kumulati }} \\
\text { f }\end{array}$ & $\mathbf{F}_{\text {relatif }}$ \\
\hline 1 & $65-69$ & 2 & 2 & $9,09 \%$ \\
\hline 2 & $70-74$ & 3 & $5 z$ & $\begin{array}{l}13,63 \\
\%\end{array}$ \\
\hline 3 & $75-79$ & 5 & 10 & $\begin{array}{l}22,72 \\
\%\end{array}$ \\
\hline 4 & $80-84$ & 7 & 17 & $\begin{array}{l}31,81 \\
\%\end{array}$ \\
\hline 5 & $85-89$ & 4 & 21 & $\begin{array}{l}18,18 \\
\%\end{array}$ \\
\hline 6 & $90-94$ & 1 & 22 & $4,54 \%$ \\
\hline \multicolumn{2}{|c|}{ Jumlah $\left(\sum\right)$} & $\begin{array}{l}2 \\
2\end{array}$ & & $100 \%$ \\
\hline
\end{tabular}

Berdasarkan tabel tersebut diperoleh simpulan bahwa tes kemampuan menulis naskah pidato mendapatkan nilai yang baik. Dari jumlah sampel sebanyak 22 siswa diperoleh sebanyak 12 siswa $(54,52 \%)$ perolehan nilanya di atas 79 . Secara lebih rinci dapat dijeaskan bahwa data yang diperoleh dari nilai menulis naskah pidato dengan menggunakan model pembelajaran probing prompting yang paling banyak adalah yang mendapatkan nilai antara 80-84 yaitu terdapat 7 siswa atau $31,81 \%$. Selanjuttnya rentang nilai 75-79 terdapat 5 siswa $22,72 \%$, lalu 4 siswa atau $18,18 \%$ berada dalam rentang $85-$ 89 , kemudian rentang nilai antara 7074 terdapat 3 siswa atau $13,62 \%$, dan yang mendapatkan nilai 65-69 diperoleh 2 siswa atau 9,09\% sedangkan yang mendapatkan nilai 9094 yaitu hanya 1 siswa atau 4,54\%. oleh 1 siswa. DeDari siswa yang menjadi sampel didapat sebanyak 12 siswa atau 54,52\% memperoleh nilai lebih dari 80.
Tabel 3

Uji Homogenitas dengan

Menggunakan Varians Terkecil dan Varians Terbesar

\begin{tabular}{|c|c|c|}
\hline $\begin{array}{l}\text { Nilai } \\
\text { Varians } \\
\text { Sampel }\end{array}$ & $\begin{array}{l}\text { Kemampua } \\
\text { n menulis } \\
\text { naskah } \\
\text { pidato } \\
\text { menggunak } \\
\text { an model } \\
\text { probing } \\
\text { prompting } \\
\text { (E) }\end{array}$ & $\begin{array}{l}\text { Kemampuan } \\
\text { menulis } \\
\text { naskah pidato } \\
\text { menggunakan } \\
\text { model } \\
\text { ekspositori }(\mathrm{K})\end{array}$ \\
\hline $\begin{array}{l}\text { Rata- } \\
\text { rata }\end{array}$ & 79,5 & 70,79 \\
\hline $\mathbf{S}^{2}$ & 44,64 & 27,84 \\
\hline $\mathbf{S}$ & 6,68 & 5,27 \\
\hline $\mathbf{N}$ & 22 & 25 \\
\hline
\end{tabular}

Berdasarkan uji persyaratan analisis, diketahui bahwa kedua data tersebut berdistribusi normal dan homogen, maka pengujian hipotesis dapat dilakukan dengan uji kesamaan dua rata-rata melalui perhitungan uji-t dua sampel. Hipotesis penelitian yang di uji adalah: "terdapat pengaruh positif model pembelajaran probing prompting terhadap kemampuan menulis naskah pidato".

\section{Tabel 4}

\section{Bantu Pengujian Hipotesis}

\begin{tabular}{|l|l|l|}
\hline $\begin{array}{l}\text { Varians } \\
\text { dan } \\
\text { Mean }\end{array}$ & Ekspeimen & Kontrol \\
\hline $\mathrm{S}^{2}$ & 44,64 & 27,84 \\
\hline $\mathrm{IX}$ & 79,5 & 70,79 \\
\hline $\mathrm{N}$ & 22 & 25 \\
\hline
\end{tabular}

Dari tabel tersebut tampak bahwa rata-rata hasil belajar menulis naskah pidato antara kelas eksperimen dan kelas kontrol memiliki selisih 8,71. Hal ini menunjukkan ada perbedaan antara nilai rata-rata postes kelas 
eksperimen dan postes kelas kontrol, yaitu nilai rata-rata kelas eksperimen adalah 79,5, lebih besar dari pada nilai rata-rata kelas kontrol 70,79. Namun perbedaan ini belum dapat dijadikan kesimpulan apakah terdapat pengaruh atau tidak. Maka langkah selanjutnya, penulis melakuka uji $\mathrm{t}$ dua sampel untuk mengetahui perbedaan kemampuan menulis naskah pidato antara kelas eksperimen dengan kelas kontrol.

Berdasarkan uji hipotesis diketahui bahwa nilai $t_{\text {hitung }}$ sebesar 5,00 sedangkan nilai $\mathrm{t}_{\text {tabel }}$ adalah 2,026 dengan $\alpha 5 \%$ dan derajat kebebasan $(\mathrm{dk})=\mathrm{n}_{1}+\mathrm{n}_{2}-2=22+25-2=45$. Dengan demikian $t_{\text {hitung }}>t_{\text {tabel }}$ atau 5,00 $>$ 2,026. Hal itu berarti, $\mathrm{H}_{\mathrm{O}}$ ditolak dan $\mathrm{H}_{\mathrm{i}}$ diterima, maka dengan demikian dapat dsimpulkan bahwa terdapat pengaruh penggunaan model pembelajaran probing prompting terhadap kemampuan menulis naskah pidato.

\section{SIMPULAN}

Berdasarkan analisis data dan pengujian hipotesis yang ada, serta menurut hasil penelitian, maka dapat disimpulkan bahwa:

1. Kemampuan menulis naskah pidato dengan menggunakan model pembelajaran probing prompting siswa kelas IX MTs. Malnu Kabupaten Lebak sebagai kelas eksperimen baik. Hal tersebut ditunjukan bahwa rata-rata kemampuan tersebut adalah 79,5 dengan nilai terendah 65 dan nilai tertinggi 90, memiliki nilai median 80,2 dan modus 81,5.

2. Kemampuan menulis naskah pidato dengan menggunakan model ekspositori pada siswa kelas IX MTs. Malnu Kabupaten Lebak sebagai kelas kontrol cukup. Hal tersebut ditunjukan bahwa rata-rata kemampuan tersebut adalah 70,79 dengan nilai terendah 60 dan nilai tertinggi 80 , dengan nilai median 71,78 dan modus 72,5.

3. Terdapat pengaruh model pembelajaran probing prompting terhadap kemampuan menulis naskah pidato pada siswa kelas IX MTs. Malnu Kabupaten Lebak. Hal tersebut ditunjukan oleh hasil pengujian hipotesis (Uji t) dengan taraf signifikan 0,05 yaitu $\mathrm{t}_{\text {hitung }}$ 5,00 lebih besar dari $t_{\text {tabel }} 2,026$ maka $\mathrm{H}_{\mathrm{O}}$ ditolak dan $\mathrm{H}_{\mathrm{I}}$ diterima. Maka terbukti bahwa terdapat pengaruh positif penggunaan model pembelajaran probing prompting terhadap kemampuan menulis naskah pidato pada siswa kelas IX MTs. Malnu Kabupaten Lebak tahun pelajaran 2015/2016.

\section{SARAN}

Hasil penelitian menunjukan bahwa kemampuan menulis naskah pidato dengan menggunakan model pembelajaran probing prompting lebih baik dari pada model ekspositori, karena itu penulis menyarankan:

1. Guru, sebelum siswa belajar menulis naskah pidato dengan menggunakan model pembelajaran, probing prompting sebaiknya guru mengondisikan siswa agar memahami tujuan yang ingin dicapai dari kegiatan tersebut, kemudian memberikan motivasi, melatih siswa mengarahkan panca indera untuk menangkap informasi.

2. Pembelajaran bahasa Indonesia dengan menggunakan model pembelajaran probing prompting dapat digunakan sebagai alternatif bagi peserta didik MTs. Malnu Kabupaten Lebak untuk meningkatkan hasil belajar menulis naskah pidato.

3. Hasil penelitian ini dapat dijadikan sebagai bahan pertimbangan untuk mengajar bahasa Indonesia di MTs. Malnu Kabupaten Lebak, sebagaimana yang diharapkan 
dalam pencapaian kompetensi dasar.

\section{DAFTAR PUSTAKA}

Djibran, Fahd. 2008. Writing is Amazing. Yogyakarta: Juxtapose.

Fitiana, Dewi Utami. 2013. Public Speaking Kunci Sukses Bicara di depan Public Teori dan Praktik. Yogyakarta: Pustaka Pelajar.

Huda, M. 2013. Model-model Pengajaran dan Pembelajaran . Yogyakarta: Pustaka Belajar.

Mayasari dkk. 2014. Penerapan Teknik Probing Prompting dalam Pembelajaran

Rakhmat, Jalaluddin. 2005. Psikologi Komunikasi. Bandung: Remadja Rosdakarya Offset

2007. Retorika Modern. Bandung: PT. Remaja Rosdakarya Offset

Sugiyono. 2008. Metode Penelitian Kuantitatif Kualitatif dan $R \& D$. Bandung: Alfabeta

Suherman, Erman. 2003. Evaluasi Proses dan Hasil Belajar Matematika. Jakarta: Universitas Terbuka.

Surakhmad, Winarno. 2010 Metodelogi Pengajaran Nasional. Jakarta: Gramedia

Syafi'ie, I. 2008. Retorika dalam Menulis. Jakarta: Depdiknas.

Tarigan, H.G. 2004. Berbicara Sebagai Suatu Keterampilan Berbahasa. Bandung: Angkasa 2008. Menulis Sebagai Suatu Keterampilan Berbahasa. Bandung: Angkasa

Wiyanto, Asul. 2005. Kesastraan Sekolah Penunjang Pembelajaran Bahasa

\author{
Indonesia SMP dan SMA. \\ Jakarta: Grasindo. \\ Zainurrahman. 2013. Menulis Dari \\ Teori Hingga Praktik. Bandung: \\ Alfabeta
}

